\title{
Preclusive Effect of Factual Determinations of the International Trade Commission with Regard to Patent Matters
}

\author{
Douglas P. Martin $\dagger$
}

In the Trade Act of $1974,{ }^{1}$ Congress created the International Trade Commission ("ITC") to investigate and punish unfair trade practices. One of the ITC's powers is to provide adequate remedies for unfair trade practices by foreign parties. Congress supplied the ITC with expansive jurisdiction and remedial powers to stop unfair trade practices and, in so doing, created an attractive forum for domestic producers wishing to assert their rights. ${ }^{2}$ In particular, Congress gave the ITC the authority to block the importation of products that infringe a valid United States patent-a power that often requires the ITC to determine whether the patent itself is valid. ${ }^{3}$

However, Congress has also granted federal district courts original and exclusive jurisdiction over cases arising under the United States patent laws. ${ }^{4}$ As a result, there are two forums

$\dagger$ B.S. 1992, University of Ilinois; J.D. Candidate 1995, The University of Chicago.

1 Pub L No 93-618, 88 Stat 1978, codified as amended at 19 USC $\$ \$ 2101$ et seq (1988 \& Supp 1993).

${ }^{2}$ See Robert G. Krupka, Philip C. Swain, and Russell E. Levine, Section 337 and the GATT: The Problem or the Solution?, 42 Am U L Rev 779, 789-807 (1993) (discussing the relative advantages of ITC adjudication). For a general discussion of the practice and procedure of the ITC in suits under $\$ 337$, see William L. Lafuze and Patricia F. Stanford, An Overview of Section 337 of the Tariff Act of 1930: A Primer for Practice Before the International Trade Commission, 25 John Marshall L Rev 459 (1992); Kenneth E. Krosin and Holly D. Kozlowski, Patent-Based Suits at the International Trade Commission Following the 1988 Amendments to Section 337, 17 AIPLA Q J 47 (1989). For a more comprehensive treatment of the practice and procedure of the ITC under $\S 337$, including a discussion of how to bring a $\S 337$ unfair competition action, see Donald Knox Duvall, Federal Unfair Competition Actions: Practice and Procedure Under Section 337 of the Tariff Act of 1930 (Clark Boardman, 1990).

319 USC $\S 1337(a)(1)(B)(1988)$ (" $[T]$ he following are unlawful, and when found by the [ITC] to exist shall be dealt with, in addition to any other provision of law, as provided in this section: ... The importation into the United States, the sale for importation, or the sale within the United States after importation by the owner, importer, or consignee, of articles that (i) infringe a valid and enforceable United States patent ... or (ii) are made, produced, processed, or mined under, or by means of, a process covered by the claims of a valid and enforceable United States patent.").

428 USC § 1338(a) (1988) ("The district courts shall have original jurisdiction of any 
that may determine patent validity, ${ }^{5}$ raising the question whether one forum's determinations will have a preclusive effect ${ }^{6}$ on a case in the other forum. It is well settled that a district court determination will have full preclusive effect in a subsequent ITC proceeding. ${ }^{7}$ In addition, most courts agree that determinations of the ITC with respect to patent validity do not have preclusive effect in subsequent district court actions involving the same case or the same issue. ${ }^{8}$ However, the preclusive effect, if any, of factual determinations the ITC makes remains to be settled.

Section I of this Comment examines the general legal background of this issue, including the overlapping jurisdiction of the ITC and the district courts, the general law of collateral estoppel, the collateral estoppel effects of federal agency determinations, and the current law with respect to the collateral estoppel effects of ITC determinations. Section II asserts that while Congress intended to deny preclusive effect to legal determinations of the ITC involving patent issues, it did not intend to deny preclusive

civil action arising under any Act of Congress relating to patents, plant variety protection, copyrights and trade-marks. Such jurisdiction shall be exclusive of the courts of the states in patent, plant variety protection and copyright cases.").

5 A "valid" patent is one that is found by a court or other competent tribunal to meet the statutory requirements of 35 USC $\S \S 100-21,161-62,171$ (1988 \& Supp 1993). A patent enjoys a presumption of validity in litigation. 35 USC $\S 282$ (1988 \& Supp 1992). As such, the claim of invalidity becomes an important defense in $\$ 337$ unfair-tradepractice actions as well as in district court infringement actions. For an in-depth treatment of the defense of invalidity, see Donald S. Chisum, 5 Patents: A Treatise on the Law of Patentability and Infringement § 19.02 (Matthew Bender, 1994).

- "Preclusive effect," as used in this Comment, refers generally to collateral estoppel (issue preclusion), res judicata (claim preclusion), or both, depending on the context. The term "res judicata," which is sometimes used as a synonym for claim preclusion, is sometimes used to refer generally to both issue and claim preclusion. This Comment will employ the terms "collateral estoppel" and "res judicata," instead of the terms "issue preclusion" and "claim preclusion," respectively, because these are the terms more commonly used by the courts; note, however, that the Restatement (Second) of Judgments has adopted the more modern terms "issue preclusion" and "claim preclusion." See Restatement (Second) of Judgments $\$ \$ 17,27$ (1982).

7 See, for example, Young Engineers, Inc. v ITC, 721 F2d 1305, 1315-16 (Fed Cir 1983) (district court determination is res judicata in subsequent ITC litigation).

${ }^{8}$ See In re Convertible Rowing Exerciser Patent Litigation, 721 F Supp 596, 603-04 (D Del 1989) ("Convertible I") (ITC determinations of patent validity not entitled to preclusive effect in subsequent district court litigation); Tandon Corp. v ITC, 831 F2d 1017, 1019 (Fed Cir 1987) (as to a patent infringement determination of the ITC, "appellate treatment of decisions of the [TTC] does not estop fresh consideration by other tribunals"); Union Manufacturing Co., Inc. v Han Baek Trading Co., Ltd., 763 F2d 42, 45 (2d Cir 1985) ("Patent validity determinations of the ITC are properly not accorded res judicata effect because the ITC has no jurisdiction to determine patent validity except to the limited extent necessary to decide a case otherwise properly before it."); Baltimore Luggage Co. $v$ Samsonite Corp., 727 F Supp 202, 207 (D Md 1989) ("the ITC would have no power to enter an order on patent validity that would have preclusive effect"). 
effect to factual determinations of the ITC involving patent issues. Finally, Section III argues that courts should grant preclusive effect to ITC factual determinations involving patent issues.

\section{LEGAL BACKGROUND}

Congress granted the ITC jurisdiction over unfair trade practices, including those cases involving the importation of goods that infringe a valid U.S. patent. ${ }^{9}$ Congress also allowed respondents in an ITC action to plead all equitable and legal defenses, which, in a patent case, include the invalidity of the patent allegedly infringed. ${ }^{10}$ Therefore, patent validity can be a deciding issue in patent cases before the ITC. However, Congress also gave federal district courts original and exclusive jurisdiction to hear patent cases. ${ }^{11}$ Thus, Congress has established two forums that have overlapping jurisdiction in the area of patent validity, thereby raising the issue of preclusive effect. ${ }^{12}$

\section{A. Collateral Estoppel}

The doctrine of collateral estoppel provides that "[w]hen an issue of fact or law is actually litigated and determined by a valid and final judgment, and the determination is essential to the judgment, the determination is conclusive in a subsequent action between the parties, whether on the same or a different claim."13 This doctrine was developed to protect parties from expensive and vexatious litigation, improve judicial efficiency, en-

\footnotetext{
919 USC $\S 1337(a)(B)(i)$-(ii).

10 Id § 1337(c).

1128 USC \& 1338(a).
}

12 See, for example, Michael A. Ritscher, et al, The Status of Dual Path Litigation in the ITC and the Courts: Issues of Jurisdiction, Res Judicata and Appellate Review, 18 AIPLA Q J 155 (1990) (discussing the conflicting jurisdiction of the ITC and the district courts and the resulting problem of dual-path litigation); Harvey Kaye, R.V. Lupo, and Steven E. Lipman, The Jurisdictional Paradigm Between the United States International Trade Commission and the Federal District Courts, $64 \mathrm{~J}$ Pat Off Society 118 (1982) (discussing many of the same issues but published before the Omnibus Trade and Competitiveness Act of 1988, see text accompanying notes 83-90).

${ }^{23}$ Restatement (Second) of Judgments $\S 27$ (cited in note 6). See also Montana $v$ United States, 440 US 147, 153 (1979) ("Under collateral estoppel, once an issue is actually and necessarily determined by a court of competent jurisdiction, that determination is conclusive in subsequent suits based on a different cause of action involving a party to the prior litigation."); Parklane Hosiery Co., Inc. $v$ Shore, 439 US 322, 326 n 5 (1979) ("Under the doctrine of collateral estoppel ... the second action is upon a different cause of action and the judgment in the prior suit precludes relitigation of issues actually litigated and necessary to the outcome of the first action."). 
force repose, and encourage respect for the judiciary by curbing inconsistency. ${ }^{14}$

Courts will only apply collateral estoppel if certain requirements are met. First, the issue in the second action must be the same as the issue in the first action. Second, the issue must have been actually litigated and decided in the first action-collateral estoppel does not preclude litigation of issues that could have been, but were not, raised in the first action. Third, both parties must have had a full and fair opportunity to litigate the issue in the first action. Fourth, the disposition of the issue in the first action must have been final, on the merits, and valid. Finally, the determination of the issue must have been essential to the judgment. ${ }^{15}$ Collateral estoppel will not preclude subsequent litigation of an issue if its determination was accompanied by the determination of another issue and either determination would have been sufficient to support the prior decision. In such a case, neither determination is considered necessary to the prior judgment. ${ }^{16}$ Only when courts are satisfied that a proceeding meets these five requirements will they grant preclusive effect to the factual determinations of a forum.

\section{B. Collateral Estoppel and Federal Agency Determinations}

With the expanding jurisdiction of administrative agencies and the increasing similarity between judicial and administrative adjudicatory procedures, courts have begun to hold that the adjudicatory determinations of such agencies are worthy of collateral estoppel. ${ }^{17}$ Extending collateral estoppel to agency determina-

14 Montana, 440 US at 153-54; Note, Collateral Estoppel Effects of Administrative Agency Determinations: Where Should Federal Courts Draw the Line?, 73 Cornell L Rev 817, 821-23 (1988).

${ }_{15}$ Charles Alan Wright, Arthur R. Miller, and Edward H. Cooper, 18 Federal Practice and Procedure $\S 4416$ at 137-38 (West, 1981). See also Restatement (Second) of Judgments $\$ 27 \&$ comment e (cited in note 6).

${ }_{16}$ Restatement (Second) of Judgments $\$ 27$ comments g, h (cited in note 6). See also Cromwell $v$ County of Sac, 94 US 351, 353 (1876) ("In all cases . . . where it is sought to apply the estoppel of a judgment rendered upon one cause of action to matters arising in a suit upon a different cause of action, the inquiry must always be as to the point or question actually litigated and determined in the original action, not what might have been thus litigated and determined. Only upon such matters is the judgment conclusive in another action.").

${ }^{17}$ See Note, 73 Cornell $\mathrm{L}$ Rev at 821-34 (providing a comprehensive discussion of collateral estoppel and federal agency determinations, including the policy behind the doctrine of collateral estoppel and the procedural requirements necessary for agency determinations to be granted collateral estoppel effect). See also Restatement (Second) of Judgments $\S 83$ (cited in note 6); Wright, Miller, and Cooper, 18 Federal Practice and 
tions promotes repose, thus furthering one of the primary purposes of collateral estoppel doctrine. ${ }^{18}$ In order for collateral estoppel to apply to an agency determination, courts have required that Congress must not have intended otherwise and that the agency must have acted in an adjudicatory capacity.

\section{Statutory scheme.}

The Supreme Court recognized the extension of collateral estoppel to agency determinations in United States $v$ Utah Construction \& Mining Co., stating that, "[w]hen an administrative agency is acting in a judicial capacity and resolves disputed issues of fact properly before it which the parties have had an adequate opportunity to litigate, the courts have not hesitated to apply res judicata to enforce repose." ${ }^{p 19}$ The American Law Institute has adopted this rule in its Restatement (Second) of Judgments, stating that "a valid and final adjudicative determination by an administrative tribunal has the same effects under the rules of res judicata, subject to the same exceptions and qualifications, as a judgment of a court." ${ }^{20}$ Administrative determinations that meet the requirements of collateral estoppel doctrine have preclusive effect both for subsequent proceedings in the same agency and for proceedings in other administrative agencies or courts. ${ }^{21}$

Courts will apply collateral estoppel to agency determinations only if such an application is supported by congressional intent. In Astoria Federal Savings \& Loan Ass'n $v$ Solimino, the Supreme Court stated that it has "Iong favored application of the common-law doctrines of collateral estoppel (as to issues) and res judicata (as to claims) to those determinations of administrative bodies that have attained finality." 22 The Court noted, however, that "[c]ourts do not ... have free rein to impose rules of preclusion, as a matter of policy, when the interpretation of a statute is at hand. In this context, the question is not whether administrative estoppel is wise but whether it is intended by the legisla-

Procedure $\S 4475$ at 762-72 (cited in note 15); Kenneth Culp Davis and Richard J. Pierce, Jr., 2 Administrative Law Treatise § 13.4 at 259-64 (Little, Brown, 3d ed 1994).

${ }_{18}$ University of Tennessee $v$ Elliot, 478 US 788, 798 (1986).

29384 US 394, 422 (1966).

20 Restatement (Second) of Judgments $\$ 83$ (cited in note 6). Here the term "res judicata" is used to refer to preclusion generally, including both res judicata (claim preclusion) and collateral estoppel (issue preclusion).

${ }_{21}$ Id $\$ 83$ comment a.

22501 US 104, 107 (1991). 
ture."23 The Astoria court recognized that Congress legislates against background rules of the common law, including the doctrine of preclusive effect. It also recognized that Congress can, in creating administrative agencies, decide for itself whether preclusive effect will apply to the agencies' determinations. ${ }^{24}$ Congress need not, however, explicitly state its intention to deny preclusive effect as long as it can be fairly implied. ${ }^{25}$

\section{Requirement of adjudication.}

For collateral estoppel to apply, the agency must not only meet the congressional intent requirement but also have jurisdiction over the particular issue the subsequent court considers. The agency must also follow procedures substantially similar to those formal procedures traditional judicial tribunals use. ${ }^{26} \mathrm{~A}$ court may be justified in refusing to grant collateral estoppel if it doubts "the quality, extensiveness, or fairness of procedures" the agency followed. ${ }^{27}$ Some courts have refused to grant collateral estoppel where there were significant differences between an agency's and a court's discovery and evidentiary procedures, or in a party's ability to take advantage of such procedures. ${ }^{28}$

However, not every procedural difference warrants a denial of preclusion. Courts have granted collateral estoppel to some administrative adjudications despite the agencies' lack of juries, differences in discovery practice, and perceived limitations on the amount of evidence that will be admitted by the administrative tribunal. ${ }^{29}$ Only more substantial differences in procedure between the two forums can defeat collateral estoppel. ${ }^{30}$

It is important to note that even if an agency's procedures are considered adequate, its decisions will not necessarily be given preclusive effect. Courts are willing to apply collateral estoppel more readily in two situations: (1) when the administrative agency has expertise regarding the particular issue involved;

\footnotetext{
23 Id at 108.

24 Id at 108-09.

$25 \mathrm{Id}$.

${ }_{26}$ Note, 73 Cormell L Rev at 828-29 (cited in note 14). See also Restatement (Second) of Judgments $\$ 83$ comment b (cited in note 6 ).

27 Montana $v$ United States, 440 US 147, 164 n 11 (1979). See also Restatement (Second) of Judgments $\$ 28$ (cited in note 6).

28 See Wright, Miller, and Cooper, 18 Federal Practice and Procedure $\$ 4423$ at 222 \& nn 16-17 (cited in note 15) (citing cases).

29 Id $\$ 4475$ at $766 \&$ nn 11-13.

so Id $\$ 4475$ at 766 .
} 
or (2) when failure to apply collateral estoppel would lead to multiple and vexatious litigation. In contrast, the judiciary may refuse to apply collateral estoppel when: (1) some greater public interest is served by denying it; or (2) doing so in a particular case would prevent a manifest injustice to a particular party. ${ }^{31}$

\section{Preclusive Effect of ITC Patent Determinations}

Consistent with the doctrine of administrative res judicata, courts generally grant preclusive effect to ITC determinations in nonpatent cases..$^{32}$ Most courts, however, agree that ITC patent validity determinations do not have preclusive effect in subsequent actions in district courts. ${ }^{33}$ Recently, the District of Delaware has taken a somewhat unique position, distinguishing between legal determinations and factual determinations of the ITC and granting preclusive effect only to the latter. ${ }^{34}$

31 See Note, 73 Cornell L Rev at 834 \& nn 110-13 (cited in note 14) (citing cases).

32 Union Manufacturing Co., Inc. v Han Baek Trading Co., Ltd., 763 F2d 42, 46 (2d Cir 1985) (granting preclusive effect to ITC adjudication of trademark infringement action); Baltimore Luggage Co. $v$ Samsonite Corp., 727 F Supp 202, 207 (D Md 1989) (same).

${ }^{33}$ In re Convertible Rowing Exerciser Patent Litigation, 721 F Supp 596, 602-03 (D Del 1989) ("Convertible $I^{\prime}$ ) (refusing to grant preclusive effect to ITC patent validity determination); Mag Instrument, Inc. v J. Baxter Brinkmann Intl. Corp., 123 FRD 543, 547 (N D Tex 1988) (denying preclusive effect to ITC determination of patent enforceability); Tandon Corp. v ITC, 831 F2d 1017, 1019 (Fed Cir 1987) (remarking that the Federal Circuit's appellate treatment of ITC decisions "does not estop fresh consideration by other tribunals"); Union Manufacturing, $763 \mathrm{~F} 2 \mathrm{~d}$ at $\mathbf{4 5}$ (stating that "[p]atent validity determinations of the ITC are properly not accorded res judicata effect ... .); Glasstech, Inc. v AB Kyro Oy, 635 F Supp 465, 468 (N D Ohio 1986) (mentioning, in the context of assessing one party's probability of success on the merits, that "the ITC proceedings are not res judicata"); Baltimore Luggage, 727 F Supp at 207 (asserting that the "ITC would have no power to enter an order on patent validity that would have preclusive effect"). See also Note, Res Judicata Effect of United States International Trade Commission Patent Decisions, 6 BYU J Pub L 127, 133 n 33 (1992), citing Dudley Shearing Machine Manufacturing Co. $v$ LaBounty Manufacturing Co., No C-C-86-295-M, slip op (W D NC, Mar 17, 1988) (citing Dudley as a case granting preclusive effect, but admitting that "the majority of district courts ... have not granted preclusion to ITC patent decisions .... .).

${ }^{34}$ In re Convertible Rowing Exerciser Patent Litigation, 814 F Supp 1197 (1993) ( $"$ Convertible $I I ")$. This decision, however, may not be as unprecedented as it purports to be. The Southern District of New York, in Teletronics Proprietary, Ltd. v Medtronic, Inc., 687 F Supp 832, 845-47 (1988), granted collateral estoppel effect to an ITC finding of the existence of a license under a patent. The court stated that "[b]ecause the federal courts have exclusive jurisdiction over patent claims, the ITC may consider issues of patent validity only insofar as they impact its decision on unfair competition claims. This does not mean, however, that the federal courts have exclusive jurisdiction over all questions which in some way concern a patent." Id at 846 (footnotes and citations omitted). The court then held that because the factual determination at issue-the existence of a license-was necessary to the adjudication of a contract claim properly before the ITC, rather than for a determination of patent validity, the defendant was collaterally estopped 
The decision in In re Convertible Rowing Exerciser Patent Litigation ("Convertible $I$ ") ${ }^{35}$ exemplifies the majority rule regarding the preclusive effect of ITC patent determinations. In Convertible $I$, the District Court for the District of Delaware concluded that ITC patent determinations do not have preclusive effect in subsequent litigation in district courts. ${ }^{36}$ The court recognized that denying preclusive effect to determinations of the ITC would give rise to a number of substantial practical and prudential problems. ${ }^{37}$ It also had trouble reconciling the denial of preclusive effect with the Supreme Court's decision in Blonder-Tongue Laboratory, Inc. $v$ University of Illinois Foundation, which held that a patent holder can not relitigate a patent previously found invalid in a suit against another party. ${ }^{38}$ The denial of preclusive effect was especially troublesome to the Convertible I court because it believed that the party against whom preclusion was being asserted had been afforded a full and fair opportunity to litigate its claim. ${ }^{39}$ Nonetheless, the court felt obligated to deny preclusive effect. The court asserted that the questions that the district court and the ITC must answer are different "in both form and substance" because the ITC considers the patent validity question in the context of a $\S 337$ unfair trade proceeding, but the district court considers the question in the context of the patent laws. ${ }^{40}$

The court also looked to the legislative history of the Trade Act of 1974 to support its decision. Specifically, the court utilized a passage in the legislative history of that Act which states:

The Commission is not, of course, empowered under existing law to set aside a patent as being invalid or to render it

from relitigating the issue. Id at 846-47.

35721 F Supp 596 (D Del 1989).

36 Id at 603-04.

${ }^{37}$ Id at 599-600. It would create a number of practical problems, such as detrimental reliance upon the ITC determination by the party who won in the ITC adjudication, waste of both judicial and litigant resources in duplicative litigation, and disrespect of civil tribunals due to inconsistent decisions. It would also cause prudential problems if a district court was forced to hear a dispute upon which the ITC had already ruled and which the Federal Circuit had affirmed. If the district court reached a different result, the Federal Circuit might have to review a judgment contrary to its prior judgment in the same dispute. Id.

${ }^{38} 402$ US 313,350 (1971).

39 $721 \mathrm{~F}$ Supp at 600 (noting that the ITC followed procedures very similar to the Federal Rules of Civil Procedure, employed basic rules of evidence, and indicated by its fact-finding that it had a good grasp of the issues involved).

${ }^{40}$ Id at 601. 
unenforceable, and the extent of the Commission's authority under this bill is to take into consideration such defenses and to make findings thereon for the purpose of determining whether $\S 337$ is being violated. . . The Commission's findings neither purport to be, nor can they be, regarded as binding interpretations of the U.S. patent laws in particular factual contexts. Therefore, it seems clear that any disposition of a Commission action by a Federal Court should not have a res judicata or collateral estoppel effect in cases before such courts. ${ }^{41}$

The court then concluded that "[i]n order to preserve the jurisdictional structure intended by Congress in patent matters, this Court must deny preclusive effect to the ITC determination."

Although the Federal Circuit ${ }^{43}$ has yet to decide the issue directly, it has expressed its agreement that ITC determinations of patent validity have no preclusive effect in subsequent actions in district courts. In Tandon Corp. $v$ ITC, it stated in dicta that "our appellate treatment of decisions of the Commission does not estop fresh consideration by other tribunals." ${ }^{\prime 4}$ The court based its statements upon the congressional intent regarding the preclusive effect of ITC decisions, as evidenced by the statements in the legislative history of the Trade Act of $1974 .^{45}$

In addition, when the Federal Circuit reviewed the Convertible I decision, it indicated that it agreed with the denial of preclusive effect. The Federal Circuit denied a petition for permission to take an interlocutory appeal from the Convertible I decision, and the petitioner moved for rehearing. In denying the petition for rehearing, the Federal Circuit stated that the petition was frivolous because, among other things, the court had numerous times before considered the question of whether an ITC determination of patent validity, affirmed on appeal, should be given preclusive effect. ${ }^{46}$ Each time, the Federal Circuit ex-

${ }^{41}$ Id at 602, quoting Trade Act of 1974, S Rep No 93-1298, 93d Cong, 2d Sess 196, reprinted in 1974 USCCAN 7186, 7329 ("Senate Report").

42721 F Supp at 602.

${ }_{43}$ As provided in 28 USC $\S 1295$ (a)(1), (6) (1988), the Federal Circuit hears all appeals from the ITC and patent appeals from the district courts.

14 831 F2d 1017, 1019 (Fed Cir 1987), citing Lannom Manufacturing Co., Inc. v ITC, 799 F2d 1572, 1577-78 (Fed Cir 1986).

5831 F2d at 1019, citing Senate Report at 7329.

46 In re Convertible Rowing Exerciser Patent Litigation, 903 F2d 822, 822-23 (Fed Cir 1990) (citing Texas Instruments Inc. v ITC, 851 F2d 342 (Fed Cir 1988); Tandon Corp., 831 F2d 1017; Lannom Manufacturing, 799 F2d 1572; Corning Glass Works v ITC, 799 F2d 1559 (Fed Cir 1986)). 
pressed the view that an ITC determination of patent validity would not have preclusive effect in subsequent litigation in district court.

Recently, in In re Convertible Rowing Exerciser Patent Litigation ("Convertible $I I^{\prime}$ ), the District Court for the District of Delaware broke from the majority rule denying preclusive effect to all patent-related findings of the ITC. The court decided that factual findings of the ITC with respect to patent issues have preclusive effect in subsequent litigation in district courts. ${ }^{47}$ Prior to that decision, all courts, including the District of Delaware in Convertible $I$, had referred to ITC determinations generally when considering the preclusive effect of ITC patent determinations. However, in Convertible II, the court distinguished for the purposes of collateral estoppel between issues of law, such as the issue of patent validity, and issues of fact, such as the existence of a license under a patent. The court stated that "findings of fact may be given preclusive effect even if such effect cannot be given to legal determinations. ${ }^{n 48}$

The court examined congressional intent-as required by Astoria ${ }^{49}$-concerning whether preclusive effect should be given to the factual determinations of the ITC. The court, noting that the Trade Act of 1974 was silent on its face, turned to the legislative history. According to the court, the drafters of the Act had considered only ITC determinations of law. The court also found that Congress rejected explicit language that would have denied preclusive effect entirely and concluded that congressional intent did not bar granting preclusive effect to the factual findings. ${ }^{50}$

The court also found that the ITC proceeding had afforded the party challenging the granting of preclusive effect a full and fair opportunity to litigate the factual issues. According to the court, the ITC necessarily considered the issue of patent validity and "the relevant evidence [presented to the ITC] was identical to what would be produced and presented to this Court.. ${ }^{51}$ The court also stated that the party challenging the granting of pre-

47814 F Supp 1197, 1207 (D Del 1993).

48 Id at 1201 (citations omitted).

49501 US at 108-09.

50 Convertible II, 814 F Supp at 1203-05, distinguishing JSK $v$ Hendry County School Board, 941 F2d 1563, 1569 (11th Cir 1991) (inferring an intent to deny preclusive effect to factual findings of state administrative agencies from Congress's rejection of certain language in the Education for All Children Handicapped Act, which would have granted such an effect).

${ }^{51}$ Convertible II, $814 \mathrm{~F}$ Supp at 1208. 
clusive effect "had a full and fair opportunity to present evidence on the factual issues relative to patent validity .... . ${ }^{32}$

The District of Delaware's decision in this case is unprecedented in the sense that it explicitly distinguishes between legal determinations and factual determinations, granting preclusive effect only to factual determinations. Other courts, including the Federal Circuit, have yet to consider this decision.

\section{CONGRESSIONAL INTENT}

In Convertible II, the District of Delaware provided for preclusive effect of ITC factual determinations as to patent matters but not for preclusive effect of ITC legal determinations of patent matters. Two questions must be addressed in determining whether this approach is proper. The first question, which the Astoria decision suggests, asks whether this structure is consistent with congressional intent. If Congress intended to deny preclusive effect to both the legal and factual determinations of the ITC, then the courts have no legitimate power to grant preclusive effect to either. ${ }^{53}$ If, however, Congress has truly remained silent with respect to the preclusive effect of factual determinations, then the courts must turn to the second question: whether it is appropriate as a matter of policy to grant preclusive effect to the factual determinations. An answer to the first step of the inquiry-congressional intent-may be found through an examination of the statutes that created and later modified the ITC and the appropriate legislative history surrounding these statutes.

\section{A. The Trade Act of 1974}

The Trade Act of 1974 ("Trade Act") amended $\S 337$ of the Tariff Act of 1930 and established the ITC to investigate and punish unfair trade practices. ${ }^{54}$ The plain language of the Trade Act does not explicitly mention the preclusive effect of ITC determinations. However, a few provisions implicitly address the question. One such passage states that "[u]nfair methods of competition and unfair acts in the importation of articles into the United States ... are declared unlawful, and when found by the [ITC] to exist shall be dealt with, in addition to any other provisions of

\footnotetext{
52 Id at 1208-09.

s3 Astoria, 501 US at 107-10.

5s Trade Act $\S 341,88$ Stat at 2053 , codified as amended at 19 USC $\S 1337(\mathrm{a})(1)(\mathrm{A})$.
} 
law, as provided in this section." ${ }^{35}$ This passage could conceivably be read as evidence of congressional intent to deny preclusive effect to ITC determinations.$^{56}$ Under this reading, ITC adjudication would supplement district court adjudication. The ITC would consider the case and fashion a remedy based on its determination of the matter. In addition, a district court could independently consider the matter and implement a remedy based on its determination. Thus, there could be two separate considerations of each issue and two separate remedies in each case.

A more plausible reading of this provision of the Trade Act was offered in Baltimore Luggage Co. $v$ Samsonite Corp., in which the court stated that this passage indicates that Congress intended that the ITC should provide supplemental remedies but not necessarily supplemental adjudication. ${ }^{57}$ The passage, after all, states that "[u]nfair methods of competition and unfair acts in the importation of articles ... shall be dealt with, in addition to any other provisions of law." ${ }^{\text {"58 }}$ This reading treats the words "dealt with" as referring to remedies and not adjudication.

Under this scheme, each factual issue in a case would be considered only once, by either the ITC or the district court. The second tribunal to be presented with the same factual issue would defer to the determination of the first tribunal. The two tribunals, however, would combine their remedial powers. For example, the ITC might consider a patent case where party A, a foreign manufacturer, is found to be infringing on the patent of party B, a domestic producer, by importing a certain product. The ITC might decide to block the importation of party A's product. Under the Baltimore Luggage reading, party $\mathrm{B}$ could also take the case to the district court which, without retrying all the factual issues in the case, could provide money damages for past infringement. The advantage of such a scheme is that, without

${ }_{55}$ Id (emphasis added).

${ }^{6}$ See Comment, Res Judicata Effects of Patent and Nonpatent Determinations Under Section 337 of the Tariff Act of 1930, 15 NC J Intl L \& Comm Reg 533, 544-45 (1990) (arguing that "ITC decisions are not to displace federal court decisions but to supplement them ...").

${ }^{57} 727$ F Supp 202, 206 (D Md 1989) ("There is no support for the ITC's argument that Congress intended adjudications made during a $\$ 1337$ proceeding to be supplemental to adjudications in other proceedings. Congress's intent to provide a supplemental remedy to fight unfair competition in the importation of articles into the United States is not frustrated by giving preclusive effect to determinations made during a $\$ 1337$ proceeding.”).

${ }_{58}$ Trade Act $\S 341,88$ Stat at 2053 , codified as amended at 19 USC $\S 1337(\mathrm{a})(1)(\mathrm{A})$ (emphasis added). 
engaging in unnecessarily duplicative adjudication of the factual issues, the ITC and district court combine their remedial powers in an attempt to make the domestic producer whole. The ITC can provide a powerful remedy that looks to future conduct, while the district court can provide a remedy that attempts to compensate for past conduct. Thus, this passage can -and should-be read to support granting preclusive effect to the factual determinations of the ITC.

Another ambiguous provision in the Trade Act provides that the statutory time limit on ITC proceedings tolls when ITC proceedings are halted due to proceedings in another tribunal. This passage states that "there shall be excluded any period of time during which such investigation is suspended because of proceedings in a court or agency of the United States involving similar questions concerning the subject matter of such investigation. ${ }^{359}$ According to the Senate Report accompanying the statute, ${ }^{60}$ "suspension of [ITC] proceedings may be undertaken by the [ITC], as an exercise of its own discretion, or as a result of a court order to the same effect. ${ }^{n 1}$ This may suggest that Congress favors court adjudication over ITC adjudication since it allows a court to unilaterally halt an ITC proceeding while the court considers the question. ${ }^{62}$ It does not, however, mean that

59 Trade Act $\S 341,88$ Stat at 2053-54, codified at 19 USC $\S 1337(\mathrm{~b})(1)$.

60 The Senate Report is an explanation of the amendments made to the earlier House bill, HR 10710, 93d Cong, 1st Sess (Oct 3, 1973), in 119 Cong Rec H32849 (Oct 3, 1973), by the Senate Finance Committee. This report accompanied the bill to the floor of the Senate as the bill was reported out of committee. The Senate passed the bill as amended and the Conference Committee accepted many of the Senate amendments. Section 341 of the Senate bill, which dealt with the ITC, was accepted by the Conference Committee, and later became law, with only a slight modification that is not important to this discussion. See Senate Report at 7326-32 (cited in note 41) (explaining the provisions of the Senate bill with respect to the ITC); Trade Act, HR Rep No 93-1644, 93d Cong, 2d Sess 46, reprinted in 1974 USCCAN 7367, 7391 (stating that the Conference Committee retained the Senate language amending $\S 337$ of the Tariff Act of 1930 with slight modification). The majority of courts and commentators have accepted the Senate Report as the definitive statement of legislative intent with respect to $\S 341$ and the preclusive effect of ITC decisions. See, for example, Note, In re Convertible Rowing Exerciser Patent Litigation: Should ITC Patent Decisions Be Given Preclusive Effect in the District Courts?, 24 Cornell Intl L J 357, 361 (1991); Comment, 15 NC J Intl L \& Comm Reg at 539 (cited in note 56); Ritscher, et al, 18 AIPLA Q J at 164 (cited in note 12); Kaye, Lupo, and Lipman, $64 \mathrm{~J}$ Pat Off Society at 120 (cited in note 12). See also Convertible I, $721 \mathrm{~F}$ Supp at 602; Teletronics Proprietary, Ltd. $v$ Medtronic, Inc., 687 F Supp 832, 846 (S D NY 1988); Tandon Corp., 831 F2d at 1019; Union Manufacturing Co., Inc. v Han Baek Trading Co., Ltd., 763 F2d 42, 45 (2d Cir 1985). But see Note, 6 BYU J Pub L at 142 (cited in note 33).

61 Senate Report at 7327 (cited in note 41).

62 See Comment, 15 NC J Intl L \& Comm Reg at 544 (cited in note 56). 
Congress intended to deny preclusive effect to ITC factual determinations. No contradiction exists between favoring adjudication of questions in a court and granting preclusive effect to an agency's factual determinations. Indeed, court adjudication may be favored, for example, because the court adjudication will have full preclusive effect, while the ITC adjudication will have only limited (factual) preclusive effect. Therefore, this passage does not support the conclusion that Congress intended to deny preclusive effect to ITC factual determinations, and may even support the opposite conclusion.

While the language and structure of the Trade Act suggest that Congress contemplated the application of collateral estoppel to ITC factual determinations in patent cases, the legislative history of the Act contains a passage that could be regarded as evidence of congressional intent to deny preclusive effect. According to the Senate Report, "[t]he Commission's findings neither purport to be, nor can they be, regarded as binding interpretations of the U.S. patent laws in particular factual contexts." ${ }^{.63}$ The report concluded, "Therefore, it seems clear that any disposition of a Commission action by a Federal Court should not have a res judicata or collateral estoppel effect in cases before such courts." ${ }^{\text {"64 }}$ Some courts and commentators have concluded from these statements that Congress did not intend determinations of the ITC to have preclusive effect on either factual or legal determinations. ${ }^{65}$

This interpretation is correct with respect to legal determinations, but not correct with respect to factual determinations. The final sentence of the passage, when read out of context, may seem to support the conclusion that Congress did not intend for factual determinations of the ITC to have preclusive effect. It does state, after all, that an ITC determination "should not have a res judicata or collateral estoppel effect." ${ }^{n 6}$ This last sentence, however, is merely a conclusion drawn from the premise stated in the preceding sentence, that ITC determinations are not "binding interpretations of the U.S. patent laws. ${ }^{p 7}$

Senate Report at 7329 (cited in note 41) (emphasis added).

64 Id.

${ }^{65}$ See, for example, Tandon Corp., 831 F2d at 1019, citing Lannom Manufacturing Co., Inc. v ITC, 799 F2d 1572, 1577-78 (Fed Cir 1986); Convertible I, 721 F Supp at 602; Note, 24 Cornell Intl L J at 361 (cited in note 60).

${ }_{66}^{6}$ Senate Report at 7329 (cited in note 41) (emphasis added).

67 Id (emphasis added). 
When both key sentences in the Senate Report are read together with the knowledge that collateral estoppel in other contexts can be applied to issues of law, ${ }^{68}$ it follows that these two sentences express a congressional intent that the ITC's legal determinations, including mixed questions of law and fact, should be given neither res judicata nor collateral estoppel effect. The treatment of factual determinations (for example, the existence of a license under the patent) is not discussed in the Senate Report, and the language of the Trade Act is more compatible with a structure in which preclusive effect applies to ITC factual determinations. Therefore, while the Trade Act should be considered a bar to granting res judicata or collateral estoppel to legal determinations of the ITC, it should not be considered a bar to granting collateral estoppel to purely factual determinations of the ITC.

\section{B. The Federal Courts Improvement Act of 1982}

The Federal Courts Improvement Act of 1982 ("FCIA") changed the structure of the federal court system, especially as it relates to the ITC. Among other things, the FCIA created the Federal Circuit, giving it appellate jurisdiction over determinations of the ITC and patent cases arising in the district courts. ${ }^{70}$ Congress hoped that this would improve consistency in the com-

This subtle distinction becomes very important when one recognizes that collateral estoppel can apply to legal issues as well as to facts. Although courts generally are reluctant to apply collateral estoppel to legal issues, courts will apply collateral estoppel to some mixed questions of fact and law. Wright, Miller, and Cooper, 18 Federal Practice and Procedure § 4425 at 242-43 (cited in note 15). See also Allan D. Vestal, Preclusion/Res Judicata Variables: Nature of the Controversy, 1965 Wash U L Q 158, 171-74; Dorsey $v$ Soloman, 435 F Supp 725, 742 (D Md 1977); Commissioner of Internal Revenue v Sunnen, 333 US 591, 597-602 (1948) (sharply limiting the application of collateral estoppel with respect to legal issues). See also James William Moore, J. Desha Lucas, and Thomas S. Currier, 1B Moore's Federal Practice $\mathbf{~} 0.442(1)$ at III-555 (Matthew Bender, 1994). Courts may also apply collateral estoppel to questions of law where both the prior and subsequent litigation arise from the same transaction or occurrence and involve the same legal issues. Wright, Miller, and Cooper, 18 Federal Practice and Procedure $\$ 4425$ at 243 (cited in note 15). "Identity of the issues is established by showing that the same general legal rules govern both cases and that the facts of both cases are indistinguishable as measured by those rules." Id $\S 4425$ at 253 (footnote omitted). Such application of collateral estoppel to questions of law applies particularly to the relationship between the ITC and the district courts with respect to issues of patent validity because a determination by the ITC involves the same laws and the same transactions or occurrences as a district court's determination.

69 Pub L No 97-164, 96 Stat 25.

70 FCIA $\S 127(a), 96$ Stat at 37-38, codified as amended at 28 USC $\S 1295$ (1988). See also Note, 6 BYU J Pub I at 143 (cited in note 33). 
plex area of patent law, reduce "forum shopping" for a more favorable application of the patent laws, and alleviate the workload of the regional courts of appeals. ${ }^{71}$

However, neither the FCIA nor its legislative history contains any significant evidence that Congress intended the FCIA to grant preclusive effect to ITC legal determinations. ${ }^{72}$ In fact, courts that have addressed the issue have failed to mention the FCIA in their analyses. ${ }^{73}$ Even the Federal Circuit did not consider its own existence to be an indication that Congress intended to grant preclusive effect to ITC legal determinations. ${ }^{74}$

Arguably, the FCIA obviates, to some extent, the need for ITC legal determinations to have preclusive effect. Post-FCIA, one appellate court exists for both ITC determinations and patent appeals from the district courts. Because the Federal Circuit reviews both forums' conclusions of law de novo, the legal determinations with respect to patent validity in each action should be more consistent than they were prior to the FCIA. Both forums use the decisions of the Federal Circuit for guidance with respect to legal questions, and mistaken applications of law can be corrected on appeal.

This restructuring does not, however, obviate the need for collateral estoppel effect for factual determinations. Appellate courts generally give deference to the fact-finding of the trial court or administrative agency that is acting in an adjudicatory capacity. ${ }^{75}$ Consistent with this, the Federal Circuit gives deference to the fact-finding of district courts and the ITC. ${ }^{76}$ If ITC factual determinations do not have a preclusive effect, U.S. patent holders will be able to "forum shop" for a favorable factual determination because the district court and the ITC can conceivably reach inconsistent factual determinations. In the absence of

71 Krupka, Swain, and Levine, $42 \mathrm{Am}$ U L Rev at $827 \mathrm{n} 271$ (cited in note 2).

${ }^{72}$ See FCIA, 96 Stat 25; FCIA, S Rep No 97-275, 97th Cong, 2d Sess 1 (1982), reprinted in 1982 USCCAN 11.

73 See, for example, Convertible I, 721 F Supp at 602-03; Baltimore Luggage, 727 F Supp at 206-07.

${ }^{74}$ Tandon Corp., 831 F2d at 1019.

${ }^{75}$ See Jack H. Friedenthal, Mary Kay Kane, and Arthur R. Miller, Civil Procedure 604-08 (West, 2d ed 1993) (discussing the appellate review of factual findings of trial courts); Bernard Schwartz, Administrative Law § 10.7 at 636-40 (Little, Brown, 3d ed 1991) (discussing appellate deference to agency fact-finding).

${ }^{76}$ See Tyler Refrigeration v Kysor Industrial Corp., 777 F2d 687, 691 (Fed Cir 1985) (reviewing a district court finding of fact using the "clearly erroneous" standard); Amer. ican Hospital Supply Corp. v Travenol Laboratories, Inc., 745 F2d 1, 9 (Fed Cir 1984) (stating that the Federal Circuit reviews ITC fact-finding using the "substantial evidence" standard). 
preclusive effect of ITC factual determinations, a U.S. patent holder who brought a complaint before the ITC and lost due to an unfavorable factual determination regarding patent validity could file a complaint in a district court seeking a more favorable finding and perhaps a more favorable result. ${ }^{77}$ This essentially allows a U.S. patent holder two opportunities to litigate the factual issues pertaining to patent validity. The FCIA restructuring does not address these considerations because consolidating the avenues of appeal does not affect fact-finding. For these reasons, the need for ITC factual determinations to be granted preclusive effect is as great after the FCIA as it was before the FCIA.

In fact, one portion of the appellate structure mandated by the FCIA suggests that Congress intended ITC factual determinations to have preclusive effect. The FCIA provides for appellate review of the ITC's findings by the Federal Circuit; as the reviewing court, the Federal Circuit must apply the "substantial evidence" standard. ${ }^{78}$ This standard gives significantly more deference to the ITC's findings than the "clearly erroneous" standard applied to district court findings. ${ }^{79}$ One could conclude from this, as the Federal Circuit did in Tandon Corp., that "[i]t was the intent of Congress that greater weight and finality be accorded to the [ITC's] findings as compared with those of a trial court." This greater deference to ITC factual findings on appeal is consistent with the conclusion that Congress intended such findings to have preclusive effect in subsequent district court adjudications. Congress would be unlikely to allow for greater deference to such factual findings on appeal and at the same time deny them preclusive effect.

One could argue that Congress contemplated a scheme without preclusive effect of ITC factual findings and allowed greater deference to these findings on appeal only because parties can seek essentially de novo review in a district court. This argu-

77 This situation is due to the lack of preclusive effect for ITC legal determinations with respect to patent validity. In fact, Convertible $I I$ is an illustration of this situation.

${ }^{78}$ See 5 USC $\& 706(2)(E)(1988)$ (providing the standard of review for agency factfinding); FCIA $\S 127(6), 96$ Stat at 38 , codified at 28 USC $\S 1295(a)(6)$ (providing for jurisdiction in the Federal Circuit "to review the final determinations of the United States International Trade Commission relating to unfair trade practices in import trade, made under section 337 of the Tariff Act of 1930") (citation omitted).

${ }_{79}$ Krupka, Swain, and Levine, $42 \mathrm{Am} \mathrm{U} \mathrm{L} \mathrm{Rev} \mathrm{at} 805$ (cited in note 2) ("F]actual determinations in district court cases are reviewed under a 'clearly erroneous' standard. Because an ITC proceeding receives only a substantial evidence review, ITC findings of fact are given greater deference regarding factual issues on appeal.") (footnotes omitted).

831 F2d at 1019, citing S Rep No 96-466, 96th Cong, 1st Sess 26 (1979). 
ment, however, ascribes to Congress an intent to provide for an adjudicatory structure that encourages the allocation of tremendous resources to multiple litigation of the same issues. Because Congress operates in a legal environment that greatly disfavors multiple litigation of the same issues, such an intent should not be lightly attributed to Congress. ${ }^{81}$ The general applicability of the doctrines of collateral estoppel and res judicata is evidence of this. When Congress intends to reach a result that is contrary to the general preference of the legal culture, one would expect Congress to clearly express its intent and not rely on what is at best an ambiguous implication. ${ }^{82}$

\section{The Omnibus Trade and Competitiveness Act of 1988}

In 1988, Congress made direct changes to the ITC in the form of the Omnibus Trade and Competitiveness Act of 1988 ("OTCA"). ${ }^{83}$ The OTCA strengthened the ITC by making it easier for patent holders to establish $\S 337$ violations. ${ }^{84}$ The OTCA also elevated the issues of patent validity and enforceability to elements of the cause of action, which effectively endowed the ITC with original jurisdiction over these issues. Prior to the OTCA, the ITC did not possess original jurisdiction over these issues, and they could only be pled in a response to the complaint. ${ }^{85}$ Neither the statute nor its legislative history, however, provides any indication whether either legal or factual determinations of the ITC are to be given preclusive effect. ${ }^{86}$

Nevertheless, at least one commentator has argued that these changes show that Congress intended to grant preclusive effect to ITC determinations, both factual and legal. ${ }^{87}$ According

81 Astoria, $501 \mathrm{US}$ at 108 (" $[\mathrm{W}]$ here a common-law principle is well established, as are the rules of preclusion, the courts may take it as given that Congress has legislated with an expectation that the principle will apply except when a statutory purpose to the contrary is evident.") (citations omitted).

82 Id at 110 ("The presumption [of preclusive effect] is thus properly accorded sway only upon legislative default, applying where Congress has failed expressly or impliedly to evince any intention of the issue.").

83 Pub L No 100-418, 102 Stat 1107 (1988).

84 Krupka, Swain, and Levine, 42 Am U L Rev at 787-88 (cited in note 2); Krosin and Kozlowski, 17 AIPLA Q J at 48 (cited in note 2).

${ }^{85}$ See Note, 6 BYU J Pub L at 143 (cited in note 33); Ritscher, et al, 18 AIPLA Q J at 164 (cited in note 12).

${ }^{86}$ See OTCA, 102 Stat 1107; OTCA, HR Rep No 100-576, 100th Cong, 2d Sess 515 (1988), reprinted in 1988 USCCAN 1547.

${ }^{87}$ Note, 6 BYU J Pub L at 141-44 (cited in note 33). See also Ritscher, et aI, 18 AIPLA Q $J$ at 167 (cited in note 12). 
to this argument, the statements made in the legislative history of the Trade Act are no longer relevant because the OTCA raises patent validity to an element of the cause of action in the ITC, thus making the ITC determination worthy of preclusive effect. ${ }^{88}$

It is unlikely, however, that Congress would effect such a sweeping change without even mentioning the issue of preclusive effect. If Congress had intended to reach a result contrary to the Federal Circuit's statements in Tandon Corp., it would not have relied on a highly questionable implication. Furthermore, the District of Delaware decided Convertible I, which held that Congress intended to deny preclusive effect to ITC determinations of patent validity, after the passage of the OTCA, and the court did not even see fit to mention the Act. ${ }^{89}$

The 1988 amendments do not undermine the 1974 Congress's intention to deny preclusive effect to the ITC's legal findings. The argument, however, supports the conclusion that factual findings of the ITC should be granted preclusive effect. By raising the issues of patent validity and enforceability to elements of the cause of action and effectively giving the ITC original jurisdiction over them, the OTCA assures that the ITC will fully consider the factual issues underlying these questions. In addition, the changes wrought by the OTCA gave ITC proceedings "even more of the character of civil litigation than an administrative proceeding." Accordingly, this strengthens the argument that factual determinations of the ITC are worthy of preclusive effect.

\section{The Uruguay Round Agreements Act}

Recently, Congress made three significant changes to the procedures of the ITC in the Uruguay Round Agreements Act ("URAA"). ${ }^{91}$ Among other things, Congress removed the strict statutory time limits to which the ITC had previously been subject. $^{92}$ The URAA also enables respondents to raise counter-

${ }^{88}$ Note, 6 BYU J Pub L at 141-44 (cited in note 33); Ritscher, et al, 18 AIPLA Q J at 167 (cited in note 12).

${ }_{89}$ See Convertible I, 721 F Supp 596.

so Ritscher, et al, 18 AIPLA $Q \mathrm{~J}$ at 158 (cited in note 12).

91 Pub L No 103-465, 108 Stat 4809 (1994).

s2 URAA § 321(a)(1)(A), (B), 108 Stat at 4943, to be codified at 19 USC § 1337(b)(1), replaces language mandating time limits with the following: 
claims in cases before the ITC-something which respondents had previously been unable to do. The counterclaim, however, is then removed to a district court where it is litigated alongside the ITC proceeding. ${ }^{93}$ In addition, the URAA empowers the respondent in an ITC proceeding to stay a district court proceeding which involves the same issues in the ITC proceeding. ${ }^{94}$ After the stay is lifted, the record of the ITC proceeding "shall be admissible [in the district court] ... to the extent permitted under the Federal Rules of Evidence and the Federal Rules of Civil Procedure. ${ }^{95}$ The URAA, however, does not discuss collateral estoppel with respect to either factual or legal determinations of the ITC.

The URAA does not evidence an intent to override the congressional statement of intent in the legislative history of the Trade Act and does not grant preclusive effect to ITC legal determinations with respect to patents. The URAA wrought changes in the ITC in an attempt to bring the United States into general compliance with its international obligations and, specifically, with a 1989 GATT panel report, which found that a number of the ITC procedures were in violation of the national treatment obligation of the GATT. ${ }^{96}$ The only provision that might create an implication that Congress intended to grant preclusive effect to legal determinations with respect to patent matters is that allowing the record of the ITC proceeding to be used in the district court after the stay in the district court proceeding has been lifted. $^{97}$ This provision, however, is ambiguous as to the application of preclusive effect to ITC legal determinations.

The [ITC] shall conclude any such investigation and make its determination under this section at the earliest practicable time after the date of publication of notice of such investigation. To promote expeditious adjudication, the [ITC] shall, within 45 days after an investigation is initiated, establish a target date for its final determination.

${ }_{93}$ URAA $\S 321(\mathrm{a})(2)(\mathrm{B}), 108$ Stat at 4944 , to be codified at 19 USC $\S 1337(\mathrm{c})$.

${ }^{94}$ URAA § 321(b)(1)(A), 108 Stat at 4945-46, to be codified at 28 USC $\S 1659(\mathrm{a})$.

${ }^{95}$ URAA \& 321(b)(1)(A), 108 Stat at $4945-46$, to be codified at 28 USC $\S 1659(\mathrm{~b})$.

${ }_{96}$ S 149, 103d Cong, 1st Sess (Jan 21, 1993), in 139 Cong Rec S576, S577 (Jan 22, 1993) (statement by Senator Rockefeller, introducing a bill that was a precursor to the URAA and contained substantially similar language regarding the amendment of $\S 337$ : "The Bill ... mak[es] those changes necessary to comply with our GATT obligations, while fully maintaining the ITC's ability to act quickly and effectively against violations of U.S. intellectual property rights and other unfair trade practices."). See also United States Section 337 of the Tariff Act of 1930: Report by the Panel adopted on 7 November 1989, in General Agreement on Tariffs and Trade, Basic Instruments and Selected Documents 345 (36th Supp 1990).

${ }_{97}$ URAA § 321(b)(1)(A), 108 Stat at 4945-46, to be codified at 28 USC § 1659(b). 
The URAA's changes to ITC procedures do, however, add support to the argument for preclusive effect of ITC factual findings with respect to patents. Each of the three changes mentioned above makes the ITC proceeding more like a traditional civil adjudication than an administrative proceeding and adds weight to the argument that ITC factual determinations are worthy of preclusive effect.

\section{APPLICATION OF COLLATERAL ESTOPPEL}

The argument that Congress intended to deny preclusive effect to the ITC's factual findings concerning patent issues rests on insufficient evidence. Therefore, courts must turn to the second inquiry: whether preclusive effect is appropriate given the characteristics and procedures of the ITC.

\section{A. Requirements of Collateral Estoppel}

With regard to the patent validity determinations of the ITC, only two of the requirements for collateral estoppe ${ }^{98}$ require discussion here: (1) the issue must be the same in both actions, and (2) the proceedings must afford a full and fair opportunity to litigate. ${ }^{99}$

\section{Same issue in both actions.}

Before a court can apply collateral estoppel to an issue, it must determine that the issue in question in the second action is the same as the issue in the first. ${ }^{100}$ In Convertible I, the Delaware district court suggested that the questions presented to the ITC were different "in both form and substance" from those presented to the district court because they arose in the context of different code provisions. ${ }^{101}$ If this was the case, then the court properly concluded that issue preclusion did not apply. However, the court may have overstated the difference between the questions that the ITC and the district court consider. ${ }^{102}$ It is true

s3 See text accompanying note $\mathbf{1 5 .}$

59 The other two requirements-that the issue must have been actually litigated and determined in the first action and that the disposition in the first action must have been final, on the merits, and valid-do not warrant discussion here. They are both questions that can be determined by examining the record of the prior proceeding. In addition, neither of these requirements has been called into question with regard to the ITC.

100 Richardson v Phillips Petroleum Co., 791 F2d 641, 645 (8th Cir 1986).

101721 F Supp at 601.

102 See Ritscher, et al, 18 AIPLA Q J at 184-85 (cited in note 12). 
that the ultimate legal questions each tribunal confronts differ in form and substance. The ITC considers whether a party has engaged in "[u]nfair methods of competition and unfair acts in the importation of articles ... into the United States, ${ }^{103}$ while the district court considers the questions of patent validity and infringement. In ITC patent cases, however, the ITC considers issues of patent validity and infringement as intermediate questions. In doing so, the ITC must consider the same types of facts and apply the same body of law as would a district court determining these issues. Therefore, though the questions of patent validity and infringement occupy a different place in the decisional hierarchies of the ITC and the district court, the core issues are identical.

Furthermore, if the District of Delaware's "form and substance" argument is correct, courts should deny preclusive effect to all ITC determinations, because all issues that the ITC considers arise under $\S 337 .{ }^{104}$ However, courts have granted preclusive effect to the trademark determinations of the ITC without questioning the identity of the issues involved, even though such questions also arise in the context of $\S 337$ unfair trade actions. ${ }^{105}$ In the trademark context, courts have not cared that the issues presented to the ITC arise under a different code section than the issues presented to a district court; instead, these courts have recognized, at least implicitly, that the underlying issues are the same. ${ }^{106}$ As in the case of trademarks, the basic factual issues in patent cases before the ITC are the same as those in patent cases before the district courts. Therefore, because the requirement that the same issue be involved in both the prior and subsequent litigation does not bar collateral estoppel in the analogous trademark context, it should not bar preclusive effect of the ITC's factual determinations in patent cases.

10319 USC \& 1337(a)(1)(A).

104 See Note, 24 Cornell Intl I J at 371 (cited in note 60 ).

105 See, for example, Union Manufacturing Co., Inc. v Han Baek Trading Co., Ltd., 763 F2d 42 (2d Cir 1985); Baltimore Luggage, 727 F Supp 202. The ITC's authority to adjudicate trademark matters rests in 19 USC $\S 1337(a)(1)(C)$. District courts also have original jurisdiction over actions arising under the trademark laws. 28 USC § 1338(a).

${ }_{106}$ Union Manufacturing, 763 F2d at 45 (" $[$ W] hen the issues raised ... in the ITC proceeding are in all important respects the same as those in the District Court, res judicata should bar the relitigation of the claim in federal court.") (citations omitted); Baltimore Luggage, 727 F Supp at 207 ("[T] cisions on trademark matters should not be given preclusive effect . . ..”). 
2. Full and fair opportunity to litigate.

In order for the ITC's factual findings to have preclusive effect, it is essential that the ITC gives parties a full and fair opportunity to litigate. This requirement, which is similar to the constitutional requirement of due process, is a very important protection that alleviates some of the concerns that collateral estoppel engenders. ${ }^{107}$ Courts use this requirement to relieve the concern that parties often do not have an incentive to invest a large amount of resources in the first action when the risk, in the absence of collateral estoppel, does not warrant such an investment. ${ }^{108}$ The full and fair opportunity requirement also addresses the concern that the procedures observed in the two forums may be substantially different. These differences may result from variations in the formal procedural rules or in the ability of parties to take advantage of them. ${ }^{109}$

Litigation in the ITC is similar to that in the district courts in most respects. When determining whether a patent has been infringed by an imported article, the ITC must use the same law as that applied in the district court. ${ }^{110}$ In addition, the ITC follows procedures similar to those in the district court. ${ }^{111}$ Indeed, even though the ITC is formally bound only by the Administrative Procedure Act ("APA"), ${ }^{112}$ the rules of procedure used by the ITC were to a large extent modeled after the Federal Rules of Civil Procedure. ${ }^{113}$

Nonetheless, the procedures of the ITC vary from those followed by the district courts in two important ways. First, the

107 See Blonder-Tongue, 402 US at 329 ("Although neither judges, the parties, nor the adversary system performs perfectly in all cases, the requirement of determining whether the party against whom an estoppel is asserted had a full and fair opportunity to litigate is a most significant safeguard."). See also Fleming James, Jr., Geoffrey C. Hazard, Jr., and John Leubsdorf, Civil Procedure $§ 11.23$ at 617-18 (Little, Brown, 4th ed 1992).

108 See Wright, Miller, and Cooper, 18 Federal Practice and Procedure $\$ 4423$ at 221 (cited in note 15). This concern may be merely academic because patent cases that go to trial in the ITC probably involve rights of such substantial value that they will be disputed vigorously regardless of preclusive effect.

109 Id $\$ 4423$ at 222.

210 See Lafuze and Stanford, 25 John Marshall L Rev at 481 (cited in note 2).

11 See Ritscher, et al, 18 AIPLA Q J at 158 (cited in note 12).

1125 USC $§ \$ 500$ et seq (1988 \& Supp 1993).

113 See E. Brandan Magrab, Patent Validity Determinations of the ITC: Should U.S. District Courts Grant Them Preclusive Effect?, 75 J Pat \& Trademark Off Society 125, 131 (1993). See also Note, 73 Cornell L Rev at 819 (cited in note 14) (stating that while courts generally deem the due process requirements insufficient to satisfy the full and fair opportunity requirement, the procedures mandated by the Administrative Procedure Act, to which the ITC must adhere, are more than adequate). 
ITC's evidentiary procedures are much less restrictive than those district courts follow. Second, ITC proceedings may provide substantially less time to litigate than do district court proceedings. ${ }^{114} \mathrm{~A}$ close examination of these differences, however, reveals that they do not deny parties a full and fair opportunity to litigate.

a) Lax evidentiary rules. The evidentiary procedures of the ITC and the district courts differ substantially. Indeed, the ITC does not abide by the Federal Rules of Evidence. ${ }^{115}$ Its relaxed evidentiary rules, however, are typical of many agencies. ${ }^{116}$ The ITC rules of evidence encourage informality, and there are few restraints on what type of evidence is allowed. ${ }^{117}$ Objections to the admissibility of evidence are rarely sustained. In addition, testimony often is introduced in the form of a written statement of a witness. The counsel brings the witness in at the hearing to attest to the truth of the statement and also to submit to cross-examination. Finally, the hearsay rule is seldom enforced in the ITC. ${ }^{118}$ These differences serve to make evidentiary practice somewhat more lax than that in the district court.

Although the ITC's less restrictive rules of evidence may differ from those district courts employ, the ITC's evidentiary rules may be preferable to strict rules. By allowing all relevant evidence to be considered, the ITC may actually better provide the parties with a full and fair opportunity to litigate. On the other hand, the additional evidence that is admitted under less stringent rules may not be as credible as that which is admitted under strict rules. This suggests that decisions based on the evidence admitted under less stringent rules will be generally less accurate and less worthy of preclusive effect than decisions made based on evidence admitted under strict rules.

114 URAA $\S 321(\mathrm{a})(1)(B), 108$ Stat at 4943 , to be codified at 19 USC $\S 1337(\mathrm{~b})(1)$ (providing that the ITC shall make a determination "at the earliest practicable time"). Prior to the recent amendments, the ITC was required to complete its investigation and make its determination within one year of its instigation, or eighteen months in a "more complicated" case. 19 USC \& 1337(b)(1) (1988).

${ }_{115}$ Andrew S. Newman and Steven E. Lipman, Representing Respondents in a Section 337 Investigation of the United States International Trade Commission, 20 Intl L 1187, 1200 (1986).

${ }^{116}$ Schwartz, Administrative Law $\S 7.2$ at $371-73$ (cited in note 75). See also 5 USC $\S \S$ $551(1), 554,556$.

117 The basic evidentiary rule of the ITC states simply that "[r]elevant, material, and reliable evidence shall be admitted." 19 CFR $\$ 210.42(b)$ (1994).

11 Kaye, Lupo, and Lipman, $64 \mathrm{~J}$ Pat Off Society at 123-25 (cited in note 12). See also Newman and Lipman, 20 Intl L at 1200-01. 
This line of reasoning makes sense, however, only if it is assumed that the trier of fact cannot or does not take into account the difference in credibility of the different types of evidence. In the ITC, administrative law judges ("ALJs")-presumably experts in the area ${ }^{119}$ - consider the evidence. They should be able to assess the credibility of particular types of evidence that the Federal Rules of Evidence would not allow to be submitted to a jury. Therefore, it should not be necessary for purposes of preclusive effect of their findings that ALJs follow the strict rules of evidence, which were primarily designed to apply to jury trials. ${ }^{120}$ Accordingly, the courts may properly accept decisions based on more informal evidentiary practice because administrative tribunals are adequately able to sift through and evaluate evidence which would not be presented to judicial tribunals. ${ }^{121}$

In addition, the judiciary's frequent application of collateral estoppel to the findings and determinations of administrative tribunals other than the ITC shows that informal evidentiary procedures should not disqualify a decision from being granted preclusive effect. ${ }^{122}$ For example, courts have granted preclusive effect to the factual determinations of the National Labor Relations Board ("NLRB") even though the NLRB does not abide by the strict evidentiary procedures of the Federal Rules of Evidence. ${ }^{123}$ The evidentiary procedures of the NLRB-like those of the ITC-are governed by the APA, ${ }^{124}$ and are much more informal than the Federal Rules of Evidence. Therefore, courts should not deny preclusive effect to the factual determinations of

119 Schwartz, Administrative Law $\S 10.1$ at 624-25 (cited in note 75); Davis and Pierce, 2 Administrative Law Treatise $\S 10.1$ at 118 (cited in note 17). Administrative law judges of the ITC hear an average of nearly four cases involving patents per year, whereas district court judges average only 2.5 patent cases per year. Telephone conversation with Jeffrey Wheeldon, Office of Unfair Import Investigation, United States International Trade Commission (Oct 14, 1994); The Administrative Office of the United States Courts, United States Courts: Selected Reports A1-59 (US GPO, 1993) (documenting the number of patent cases per year in federal courts); Henry J. Reske, Developments: Help Wanted, ABA $J 34$ (Sept 1993) (stating that there are 846 total federal judgeships); Marshall Ingwerson, Clinton to Put His Own Stamp on US Courts, 85 Christian Sci Monitor 1, 4 (Apr 9, 1993) (stating that there are 649 district court judges).

120 Davis and Pierce, 2 Administrative Law Treatise $\S 10.1$ at 117-18 (cited in note 17).

121 Id; Wright, Miller, and Cooper, 18 Federal Practice and Procedure $\$ 4422$ at 216 (cited in note 15).

122 Wright, Miller, and Cooper, 18 Federal Practice and Procedure $\$ 4422$ at 216 (cited in note 15).

${ }^{123}$ Martin v Garman Construction Co., 945 F2d 1000, 1004 (7th Cir 1991); Pygatt v Painters' Local No. 277, 763 F Supp 1301, 1308 (D NJ 1991).

124 See 29 USC § 156 (1988). 
the ITC merely because the ITC follows informal evidentiary procedures.

b) Time constraints. An additional consideration in determining whether parties have a full and fair opportunity to litigate before the ITC is the time constraints of ITC proceedings. ${ }^{125}$ Until recently, the ITC proceedings were governed by strict statutory time constraints. ${ }^{126}$ The URAA, however, removed these strict limits, providing that the ITC should make its determination "at the earliest practicable time after the date of publication of notice of such investigation." 127

The removal of the strict statutory time constraints might seem to suggest that having less time to litigate before the ITC than the district court is no longer an issue. However, it is too early to tell whether the removal of the strict time limits will significantly increase the length of $\S 337$ proceedings. Indeed, it may be that the practice of the ITC with respect to duration of $\S$ 337 proceedings will not change. ${ }^{128}$

These time limits seem to give an advantage to the complainants, who choose the forum and control the timing of the litigation. As a result, they can do most of their research and preparation before filing their claim; they effectively have much more time than the statutory limit in which to prepare their cases. The respondent, however, may only learn of the action at the time it is filed with the ITC. With a relatively short period of time, the respondent may bear the large burden of retaining counsel, researching the issues, and preparing her defense. ${ }^{129}$

${ }^{225}$ Patent cases in district courts last an average of thirty-one months. Magrab, $75 \mathrm{~J}$

Pat \& Trademark Off Society at 131-32 (cited in note 113).

126 See note 114.

127 URAA \& 321(a)(1)(B), 108 Stat at 4943, to be codified at 19 USC \& 1337(b)(1).

128 Introducing a bill containing substantially similar language to the language in the $\S 337$ amendments of the URAA, Senator Rockefeller made a statement concerning the removal of the time limits:

The [ITC] has repeatedly and consistently demonstrated that it is practicable for it to conclude investigations and make determinations within 12 months, or within 18 months in especially complicated cases. This historical record clearly sets the standard for the earliest practicable time that I expect the [ITC] to maintain.

It is also my understanding . . . that it is the intention of current commissioners to maintain this standard. I am also confident that when new commissioners are nominated, the Senate Finance Committee will ask them during their confirmation hearings to commit themselves to maintaining the current standard.

$S 149$, in 139 Cong Rec at $S 578$ (cited in note 96).

${ }^{129}$ Kaye, Lupo, and Lipman, $64 \mathrm{~J}$ Pat Off Society at 126-27 (cited in note 12). 
At least one commentator has expressed concern that the ITC's time constraints place an unfair burden on the respondent. Donald Duvall, former Chief Administrative Law Judge of the ITC, has suggested that Congress relax the statutory time limits on ITC proceedings to permit more flexibility in the interest of fairness. ${ }^{130} \mathrm{He}$ questions whether the parties can have a full and fair opportunity to litigate given the time constraints placed upon the ITC action. Because of the time limitation imposed on the full proceeding, parties must comply with numerous deadlines the ITC imposes in an effort to help it fulfill the overall time constraints. These deadlines create hectic work periods for both the ALJs and the attorneys, which may decrease the quality of the proceedings. Time constraints also tend to make discovery and the professional ability and skill of counsel very important in the adjudication of a $\S 337$ action. ${ }^{131}$

Although Duvall criticizes the time constraints placed on the ITC, he acknowledges that the constraints "can function in appropriate regulatory schemes as a valuable and viable administrative device for achieving due process with dispatch. ${ }^{.132}$ In fact, Duvall admits that the ITC's statutory time constraints may be directly responsible for the success of the ITC as an adjudicatory body and the resurrection of $\S 337$ as a viable remedy for unfair trade practices. ${ }^{133}$

Courts have frequently either stated or assumed that ITC procedures in other contexts afford a full and fair opportunity to litigate. ${ }^{134}$ For example, ITC decisions concerning the validity of trademarks are generally granted preclusive effect in subsequent litigation in the district courts. ${ }^{135}$ The ITC follows the same procedures and abides by the same time constraints in trademark cases as it does in patent cases. Therefore, unless a distinction can be made between patent cases and trademark cases regarding a litigant's ability to receive a full and fair opportunity to ad-

130 See Donald K Duvall, Adjudication Under Statutory Time Limits: The ITC Experience, 32 Admin L Rev 733, 743-44 (1980).

131 Id at 736-47.

132 Id at 734 (footnote omitted).

193 Id at $742-43$.

134 Ritscher, et al, 18 AIPLA Q J at 180-81 (cited in note 12). See also Aunyx Corp. $v$ Canon U.S.A., Inc., 978 F2d 3, 8 (1st Cir 1992) (affirming a grant of preclusive effect to ITC determinations regarding antitrust claims).

235 See, for example, Union Manufacturing Co., Inc. v Han Baek Trading Co., Ltd., 763 F2d 42 (2d Cir 1985); Baltimore Luggage, 727 F Supp 202. See also Ritscher, et al, 18 AIPLA Q J at 180 (cited in note 12); Note, 24 Cornell Intl L J at 357-58 (cited in note 60). 
judicate her claim, patent determinations and trademark determinations of the ITC should be treated similarly.

The only plausible distinction that could be made between patent cases and trademark cases is that patent cases can be much more complicated because they may involve highly technical, scientific issues. The concern is that, because of the complexity of the issues, more time is needed for full and fair consideration. However, this is precisely when the ITC can designate a longer period of time as "the earliest practicable" and thereby extend the length of adjudication. Such an extension provides the ITC with additional time to consider the potentially complex issues involved in a patent case. Therefore, given the ITC's ability to allocate more time to some patent cases, the treatment of patent determinations and trademark determinations should be similar.

Additionally, with proper planning and organization, respondents can counter most of the advantage with which complainants begin the litigation. ${ }^{136}$ Because complainants have a head start in preparation, respondents must use their time wisely in order to restore a level playing field. By staying abreast of ITC proceedings, respondents can get involved in a claim during the preinstitution period, before the notice of investigation is printed in the Federal Register. Such respondents can inform the ITC about their own interpretations of transactions or occurrences and, in this way, gather information that they would otherwise have to gain through discovery. ${ }^{137}$ The respondents can also use this time to begin preparing their defenses, anticipating complainants' discovery requests, and preparing discovery requests of their own. If respondents adequately take advantage of this time, they are able to issue some of their discovery requests at the end of the preinstitution period. Also, due to the factual specificity required in a $\$ 337$ complaint, respondents gain much information from the complaint that would not ordinarily be obtained until discovery. Respondents who organize their defenses and take advantage of the preinstitution period can diminish or

136 Newman and Lipman, 20 Intl L 1187 (cited in note 115).

137 First, unlike mere notice pleading in federal district courts, a complaint submitted to the ITC must contain specific facts constituting the alleged violation. 19 CFR $§ 210.20$ (1994). Second, educating the ITC as to the respondent's view of the alleged violation may result in the ITC requesting the complainant to submit further information that the respondent might otherwise have had to obtain through discovery requests. Newman and Lipman, 20 Intl $\mathrm{L}$ at 1192 (cited in note 115). 
dissolve the complainant's advantage and should be in a good position to weather the ITC proceedings. ${ }^{138}$

\section{B. Application of Collateral Estoppel to Factual Determinations}

Besides raising the issue of whether preclusion is appropriate, the decision in Convertible II raises other issues concerning the application of collateral estoppel to ITC factual determinations. The decision questions whether a plausible distinction can be drawn between determinations of fact and determinations of law, and whether granting preclusive effect to determinations of fact will bring about de facto preclusion of legal issues.

The Supreme Court itself has drawn the distinction between legal and factual issues, recognizing that preclusive effect may sometimes apply only to the fact-finding of administrative agencies. ${ }^{139}$ In the leading case on the matter of administrative res judicata, the Court spoke only of factual findings: "[w]hen an administrative agency is acting in a judicial capacity and resolves disputed issues of fact properly before it ... the courts have not hesitated to apply res judicata to enforce repose."140

Following the Supreme Court's lead, lower courts have granted preclusive effect to factual but not legal findings of various agencies. For example, the Seventh Circuit concluded that while the NLRB's legal determinations would not preclude relitigation, its factual findings would. ${ }^{141}$ The court reasoned that the NLRB's legal determinations could not have preclusive effect because the NLRB lacks jurisdiction over causes of action under the Employee Retirement Income Security Act ("ERISA"). ${ }^{142}$ The court affirmed, however, the district court's decision to give the agency's fact-finding preclusive effect. ${ }^{143}$ The ITC is in the same position in relation to patent matters as the NLRB is in relation to ERISA. Because the ITC lacks the jurisdiction to adjudicate the issues of patent validity or infringement under the

${ }^{138}$ Newman and Lipman, 20 Intl $L$ at 1192 (cited in note 115).

${ }^{139}$ Utah Construction, 384 US at 418-22; University of Tennessee $v$ Elliot, 478 US 788, 796-99 (1986); Martin v Garman Construction Co., 945 F2d 1000, 1004 (7th Cir 1991); Pygatt v Painters' Local No. 277, 763 F Supp 1301, 1307-08 (D NJ 1991); Layne v Campbell County Department of Social Services, 939 F2d 217, 219-22 (4th Cir 1991); Noyes v Channel Products, Inc., 935 F2d 806, 809 (6th Cir 1991).

${ }^{140}$ Utah Construction, 384 US at 422 . The term "res judicata" here refers to preclusion principles generally, including both res judicata and collateral estoppel.

${ }^{141}$ Martin, 945 F2d at 1004.

112 See ERISA, 29 USC $\$ \$ 1001$ et seq (1988 \& Supp 1993).

143 Martin, 945 F2d at 1006. 
patent laws, its determinations of such legal matters should not be granted preclusive effect. Like the NLRB's factual determinations, however, ITC factual determinations should be granted preclusive effect.

Courts have also drawn a line between purely factual issues and mixed questions of law and fact. For example, the Sixth Circuit upheld the decision of a district court to grant preclusive effect to the purely factual findings of a state administrative agency and to deny preclusive effect to a finding of the same agency concerning a mixed question of law and fact. ${ }^{144}$ The court stated that:

The Board's penultimate finding ... resolved a mixed question of law and fact, and therefore was not entitled to preclusive effect.... However, the findings predicate to the Board's ultimate conclusion ... were purely factual in nature, were squarely considered by the state agency, and were therefore binding upon the district court. ${ }^{145}$

Similarly, ITC determinations regarding mixed questions of law and fact should not be granted preclusive effect. Like the state administrative agency in this case, the ITC lacks the jurisdiction to make a legal determination that will bind the district court. Its purely factual determinations, however, should be granted preclusive effect because the ITC, like the state administrative agency, squarely considers the factual issues.

The combination of preclusive effect of factual determinations of the ITC and de novo review of legal issues by the Federal Circuit should increase the consistency of results between the ITC and the district court while bringing stability to the field of patent law. This increased continuity should not be interpreted as creating a system of de facto legal preclusion. As noted by the District of Delaware, granting preclusive effect to factual determinations of the ITC does not necessarily result in de facto legal preclusion. ${ }^{146}$ First, the district court action could involve a slightly different factual context than the ITC action. Second, for those ITC determinations that are not appealed to the Federal Circuit, the district court would essentially act as a court of appeals, reviewing the law de novo but deferring to the fact-finding of the ITC. The factual determinations of the ITC would be bind-

\footnotetext{
144 Noyes, 935 F2d at 809.

145 Id (footnote omitted).

146 Convertible II, 814 F Supp at 1204 n 12.
} 
ing on the district court, but the district court would not be bound by the legal determinations of the ITC. Of course, if the district court deems the ITC's application of law to the facts incorrect, it can reach a different result through its own application of law to fact. Thus, granting preclusive effect to factual determinations will not result in de facto legal preclusion.

Though some have argued that preclusive effect should be given to both factual and legal determinations of the ITC, ${ }^{147}$ granting preclusive effect to factual determinations of the ITC but not legal determinations more closely follows the intent of Congress. As shown by examination of the relevant legislation, Congress intended to deny preclusive effect to ITC legal determinations with respect to patents but did not intend to deny preclusive effect to ITC factual determinations with respect to patent issues.

\section{Advantages of Applying Collateral Estoppel}

Granting collateral estoppel effect to ITC factual determinations in patent cases has numerous advantages. Most importantly, granting collateral estoppel effect to ITC proceedings would conserve district court resources. Collateral estoppel requires district courts to accept the factual findings of the ITC, thus saving the district court from additional investment in the factfinding process. ${ }^{148}$ Rather than reopening the same factual issues tried by the ITC, the district court will be able to rely on the record developed in the ITC action. This would save the district courts a significant amount of time that could be used to try other cases.

Granting preclusive effect would also conserve litigant resources. ${ }^{149}$ In the absence of collateral estoppel for ITC factual determinations, litigants may have to invest time and money in adjudicating the same factual issues in both the ITC and the district court. There are no substantial advantages from this duplication of effort. Scarce resources-time and money-will be

147 See Note, 6 BYU J Pub L 127 (cited in note 33); Magrab, 75 J Pat \& Trademark Off Society 125 (cited in note 113); Note, 24 Cornell Intl L J 357 (cited in note 60); Comment, 15 NC J Intl L \& Comm Reg 533 (cited in note 56); Note and Comment, The Preclusive Effect of ITC Patent Fact Findings on Federal District Courts: A New Twist on In Re Convertible Rowing Exerciser Patent Litigation, 27 Loyola LA L Rev 1417 (1994).

149 Note, 73 Cornell L Rev at 817 (cited in note 14).

149 Wright, Miller, and Cooper, 18 Federal Practice and Procedure $\S 4403$ at 14-15 (cited in note 15). 
saved by granting preclusive effect to ITC factual determinations in patent cases.

In addition, granting preclusive effect to ITC factual determinations would decrease the ability of economically stronger parties to coerce economically weaker opponents into settlement through duplicative discovery and onerous litigation. ${ }^{150}$ In the American legal system, economically stronger parties potentially possess a large advantage over economically weaker opponents: the former can generally afford to litigate a matter much more fully than the latter. Because of this, their weaker opponents may be more inclined to settle than they otherwise would be. Denying preclusive effect to ITC factual determinations can exacerbate this problem. Under these circumstances, the threat of litigation by economically stronger litigants is bolstered because they can threaten expensive and time-consuming litigation in both the ITC and a district court, perhaps leading economically weaker opponents to accept a less advantageous settlement. Granting preclusive effect to ITC factual determinations can decrease the ability of economically stronger litigants to coerce weaker parties.

Finally, application of preclusion principles would encourage parties to respect the ITC adjudicatory process and rely upon ITC fact-finding. ${ }^{151} \mathrm{~A}$ prevailing party in the ITC could act in reliance upon the ITC determination without later being called upon to relitigate factual issues that had been fully litigated and determined in the ITC. Therefore, granting preclusive effect to factual determinations would help to maintain the ITC as a viable tribunal.

The importance of maintaining the ITC as a viable tribunal should not be overlooked because the ITC has historically provided very effective remedies for infringement of U.S. patents and continues to provide a quick and effective method of border enforcement. ${ }^{152}$ As one article notes, "[t]he principal advantages of section 337 proceedings over district court actions are speed, the ITC's expertise, the ability to reach multiple parties in one forum, efficient foreign discovery, and border enforcement by the U.S. Customs Service."153 A district court provides a patent holder the options of injunctive or monetary relief, but only

\footnotetext{
150 Id $\S 4403$ at 14 .

151 Id $\S 4403$ at $12-13$.

152 See Krupka, Swain, and Levine, $42 \mathrm{Am} \mathrm{U} \mathrm{L} \mathrm{Rev} \mathrm{at} \mathrm{782-85} \mathrm{(cited} \mathrm{in} \mathrm{note} \mathrm{2).}$

153 Id at 821 .
} 
through a potentially lengthy suit. The ITC, however, can put an end to the unfair trade practices before the patent holder's market is irreversibly damaged. This is accomplished by a substantially shorter litigation period and the opportunity for total exclusion of the goods from the country through border enforcement. ${ }^{154}$ This exclusion, in turn, alleviates the common difficulty in enforcing the district court judgments and collecting damages. ${ }^{155}$ Finally, importers infringing upon U.S. patents can easily take advantage of the district court system's jurisdictional and remedial limitations and lengthy litigation. ${ }^{156}$ Because of this, "expeditious section 337 proceedings undertaken by the [ITC] ... are often the only effective remedy and deterrent to stop such unfair trade practices." ${ }^{.157}$

The protection of the viability of the ITC adjudicatory process and the reduction of duplicative litigation are important advantages of applying collateral estoppel to ITC factual determinations. The ITC has enormous power to protect domestic intellectual property rights from infringement by foreign parties. It has jurisdictional and remedial capabilities that district courts lack. Denying preclusive effect to ITC factual determinations would severely limit the importance of ITC adjudications. Granting preclusive effect to ITC factual determinations would go far to remedy the spectacle and enormous cost of dual-path litigation. In the face of these substantial advantages of granting preclusive effect to ITC factual determinations and in the absence of clear congressional intent to the contrary, courts should grant preclusive effect to ITC factual determinations.

\section{CONCLUSION}

Congress legislates against a background of common law principles of adjudication, one of which is the doctrine of preclusive effect. This doctrine of preclusive effect applies to both traditional judicial bodies and administrative agencies acting in an adjudicatory capacity. Furthermore, Congress can deny-explicitly or implicitly-preclusive effect to an agency's determinations. The administrative agency must follow procedures that are sufficiently similar to those of traditional judicial bodies

\footnotetext{
154 Id at 783. See also Lafuze and Stanford, $25 \mathrm{John}$ Marshall L Rev at 490 (cited in note 2).

${ }^{155}$ See Krupka, Swain, and Levine, $42 \mathrm{Am}$ U L Rev at 819 (cited in note 2).

156 Id at 783.

157 Id.
} 
before courts will grant preclusive effect to its decisions. Here, congressional intent states unequivocally that ITC legal determinations with regard to patent matters should be denied preclusive effect, but does not evidence a desire to deny preclusive effect to ITC factual determinations regarding patent matters. Furthermore, the ITC follows a set of procedures that are substantially similar to those followed by the district courts. In spite of the relatively lax evidentiary rules and the time constraints involved in ITC proceedings, the adjudicatory process of the ITC affords parties a full and fair opportunity to litigate. Finally, the application of collateral estoppel to ITC patent determinations has several advantages, including the maintenance of the ITC as a viable tribunal. Therefore, while courts should continue to deny preclusive effect to ITC legal determinations with respect to patent matters, they should grant preclusive effect to the factual determinations of the ITC with regard to these matters. 